\title{
Minister And Viceroy, PAisAnO AND Amigo: The Private Correspondence of the Marqués de la Ensenada and the Conde de Superunda, 1745-1749
}

\begin{abstract}
$7 \mathrm{n}$ the Archivo General de Indias in Seville there exists a remarkable sample of private correspondence between two of the most powerful figures of the Bourbon Age in Spanish American history. The principal writer is Zenón de Somodevilla y Bengoechea, marqués de la Ensenada and minister of Hacienda, War, and Indies and Marine since 1743, and subsequently holder of other posts that made him, in a contemporary opinion, "Secretary of Everything." His correspondent is José Antonio Manso de Velasco, conde de Superunda and viceroy of Peru from 1745 to 1761, the longest serving and among the most influential of the Peruvian viceroys. ${ }^{2}$ The Seville correspondence consists mainly of just seven generally brief letters. ${ }^{3}$ The private character of these letters, however, along with the close relationship between the two men and the roles they occupied, makes them historically fascinating. Excerpts are published here for the first time, in both Spanish and English translation. ${ }^{4}$
\end{abstract}

The tone of these letters is immediately striking, suggesting an exceptionally warm relationship between minister and viceroy. They address each other in the most intimate terms, as "friend of my life" or "friend of my soul." Ensenada signs off at times with "I remain yours always at heart"; at others, "I am and will be yours until death." These expressions were more than mere formulae: Ensenada handled important family affairs for Superunda during the latter's

I wish to thank the anonymous reviewers of The Americas for their constructive comments on this article.

1. John Lynch, Bourbon Spain, 1700-1808 (Oxford: Basil Blackwell, 1989), 160. On Ensenada, see for example Stanley H. Stein and Barbara H. Stein, Silver, Trade, and War: Spain and America in the Making of Early Modern Europe (Baltimore: Johns Hopkins University Press, 2000), chapt. 8. The minister's leading modern scholar is José Luis Gómez Urdáñez, whose extensive oeuvre includes El proyecto reformista de Ensenada (Lleida: Milenio, 1996).

2. See José Antonio Manso de Velasco, Relación y documentos de gobierno del Virrey del Perú, José Antonio Manso de Velasco, Conde de Superunda (1745-1761), Alfredo Moreno Cebrián, ed. (Madrid: Consejo Superior de Investigaciones Científicas, 1983).

3. These may be found in Seville at the Archivo General de Indias [hereafter AGI], Lima, legs. 642 and 643.

4. The orthography of the letters has been modernized and standardized in my edition below. Editor's note: For this reason, the British spelling has been preserved in the English translations presented here. 
posting, and at one point offers to send him trinkets he might desire from home. Still more noteworthy is Ensenada's repeated reference to both men's origins in the Rioja region of northern Spain. He evokes their common status as riojanos to urge Superunda to greater efforts in his reforms in Peru and in more expedient remissions of funds to the metropolis, at one point emphasizing that "Divine Providence has placed one of us as viceroy of Peru and the other as minister for a reason." We see comparable attitudes in Ensenada's views beyond his relationship with Superunda. In another context, he remarks, "It was absurd to send a Guipuzcoan somewhere there were parties of Basques and Montañeses" (people from Cantabria). The intense alliance to the patria chica, or home region, has a deep tradition in Spain; here we find its blunt expression at the highest level of state affairs.

The relationship between Ensenada and Superunda lies at the heart of the significance of this documentary series. In recent research, I have sought to demonstrate how relations between ministers and viceroys affected the development of policy and reform in Peru during the early Bourbon period (broadly, the first six decades of the eighteenth century). ${ }^{5}$ I argue that the dynamics between ministers and viceroys-between metropolis and colony, or center and periphery - was far more fluid and, in administrative terms, "egalitarian" than traditional readings would suggest. And nowhere is this so clear as in the relationship between the marqués de la Ensenada and the conde de Superunda, with the latter taking an active and instrumental role in the shaping of policy for Peru that went far beyond simple service as an agent for its implementation. In a wide range of areas, Superunda himself designed and carried through major aspects of imperial policy for Peru, and in some cases for other regions of the empire as well.

The Seville letters provide crucial evidence for this relationship, beginning with Ensenada's statement that he was responsible for Superunda's appointment to Peru. In fact, Superunda was but one of a group of trusted dependents placed by Ensenada in high positions throughout the colonies. ${ }^{6}$ Another was Juan Francisco de Güemes y Horcasitas, first conde de Revillagigedo and viceroy of New Spain from 1746; he is referred to in the letters as "our friend Horcasitas." Superunda is assured repeatedly of the absolute support he enjoys in Madrid, and still more crucially, that he will be furnished with whatever powers he requires to push through what I have called the "Ensenada-Manso de Velasco program for Peru."7 Thus, Ensenada writes, "You have the powers, and you

5. Adrian J. Pearce, The Origins of Bourbon Reform in Spanish South America, 1700-1763 (New York: Palgrave Macmillan, 2014).

6. Ibid., 145

7. Ibid., 169 
will be given all that you wish," and elsewhere, "You have been given powers to do so, and should you wish for more, you will be given more."

\section{Ensenada, the Viceroy's Financial Powers, AND Church-State Relations in Peru}

This delegation of power from the minister to the viceroy was to be concealed from public knowledge, but it was no less the real for that. Ensenada writes, "It is necessary that you should take a hand in affairs, throwing the stone where you see fit, and hiding the hand, since that is what I am here for, and my sword is very long." Indeed, the minister assures his friend, "Care will be taken to ensure that the orders conceding you the powers that you ask for do not refer to your reports, but you should take no notice of this, since everyone knows that you are greatly supported by the king and my ministry." 8 Moreover, Superunda should report on the things he was unable to do on his own, so he could "be sent the necessary orders"; and there are references in the letters to the viceroy's requests for additional measures or powers, in particular regarding the Peruvian treasury and his control over it.

This close relationship between Superunda and the powerful "Secretary of Everything" in Madrid sustained the unusually influential role the viceroy played in the formulation and implementation of policy in Peru during the late 1740s and early 1750s. The chief area affected, unsurprisingly, was fiscal affairs, and the chief tool handed to Superunda to achieve the ends desired in this area was the Superintendencia General de Real Hacienda, or General Superintendency of the Royal Exchequer. Created by decree in 1751, this superintendency was a major innovation in colonial fiscal organization, giving American viceroys powers denied to them during the two preceding centuries, including the absolute authority to collect, administer, and farm out the royal revenues. ${ }^{9}$ The reform originated in a proposal made by Ensenada five years earlier for the introduction to Peru of intendants with special fiscal responsibilities. Superunda had opposed this idea, seeking instead a general superintendency of the treasury for himself. Ensenada refers to this question in the last of the letters published below, dated May 9, 1749, when he writes, "A reply will be sent on what you propose regarding the creation for now of a Secretary, etc., for Exchequer affairs, since the title of Intendant sounds so bad."

8. The point here is that Superunda has sent reports making suggestions for changes in imperial policy and asking for the powers needed to implement them. Ensenada makes clear that the orders he is sending granting Superunda these powers will conceal the fact that the initiative actually originated with the viceroy.

9. For the fiscal matters discussed in this and the following paragraph, see ibid., 149-154. 
Armed with these new formal powers, but above all with the unfailing support of Ensenada, Superunda became the author of two measures of real importance to the Peruvian treasury. The first was legalization of the repartimiento de mercancia, or forced distribution of goods to indigenous communities by provincial magistrates (corregidores). Not long after Superunda arrived in Peru he discussed possible revenue-raising measures for the viceroyalty with the marqués de Casa Calderón, regent of the Tribunal de Cuentas in Lima. Casa Calderón brought to Superunda's attention the revenue forfeited by the crown through its failure to regularize (and thus to tax) the repartimiento, worth as much as two million pesos per year. Superunda acted promptly on these discussions, and in July 1746 sent a report on his proposals for legalization of repartimientos to Madrid. These proposals led some years later (in 1751) to the formation of a commission in Lima, charged with preparing detailed tariff lists on which the new system would be based. Under Superunda's presidency, this commission set to work over the following few years, until a legalized and officially controlled repartimiento based on the new regulations came into effect early in 1754. The fiscal impact of this measure was considerable: in principle, taxation of repartimientos implied an immediate increase of some 47 percent in the yield from the alcabala tax on trade within Peru. ${ }^{10}$ Even if not all this increase was actually achieved, it surely fuelled the overall increase of 60 percent in the value of the alcabala that Superunda reported during precisely this period (the early 1750s). ${ }^{11}$

Superunda's second and far greater contribution to Peruvian fiscal resources was the introduction to the viceroyalty of the estanco del tabaco, or royal tobacco monopoly. Ensenada may have discussed establishment of such a monopoly with Superunda prior to its implementation, but as the minister acknowledges in these letters, the estanco itself was wholly the viceroy's work: "The tobacco monopoly will give abundant income, and this will be entirely your undertaking." Soon after his arrival in Peru, Superunda entrusted the affair to a royal accountant, Tomás de Chavaque, who prepared a detailed project for its organization. In its eventual form, the monopoly was governed by a junta composed of members of the Royal Audiencia and presided over by Superunda himself. It was introduced over several years: proclaimed by viceregal decree in 1752, it first operated only in Lima and affected only snuff tobacco. In 1753 , it was extended to include the more popular leaf tobacco, and a separate monopoly was established for Chile; between 1754 and 1755, it was extended throughout the remainder of the viceroyalty. The estanco del tabaco proved

10. Alfredo Moreno Cebrián, El corregidor de indios y la economía peruana en el siglo XVIII (los repartos forzosos de mercancias) (Madrid: Consejo Superior de Investigaciones Científicas, 1977), 295.

11. Manso de Velasco, Relación, 348-349. Here he compares income from the alcabala at the Lima treasury for the periods $1740-44$ and $1750-54$. 
profitable virtually from the first, and in time would come to constitute among the most important sources of revenue for the Peruvian treasury. As Catalina Vizcarra has emphasized in the most recent major work on this topic, gross revenues from tobacco surpassed even silver for much of the period from 1752 onward, while "net revenues represented around 15 percent of fiscal income for most of the period." 12 Successful introduction of the estanco to Peru in the early 1750 s provides a more convincing precedent for its introduction to New Spain some 15 years later than does its much earlier establishment in Cuba, often cited in this regard.

Beyond fiscal affairs, Superunda made a signal contribution in one further area: that of church-state relations within his viceroyalty. $\mathrm{He}$ designed and implemented the most important reform in ecclesiastical matters undertaken by the Bourbons prior to the reign of Charles III: the secularization of native parishes administered by members of the regular orders. Charles Walker has demonstrated the key role Superunda played in the origins of this "secularización de doctrinas." In 1746, the viceroy sent a brace of letters proposing reform of the religious orders, ostensibly motivated by the great Lima earthquake of that year. These reports prompted the formation of a junta in Madrid in 1748 to discuss these and related proposals, and the secularization of the doctrinas was decreed in partial form in 1749 and more generally in 1753. ${ }^{13}$ Kenneth Andrien, author of the principal study of the development and consequences of the reform in Peru, concludes that secularization gave rise to "a long, steady process" of taking control from the orders, a "war of attrition" that continued from the early 1750s into the 1770s. The process was nevertheless "inexorable," and by the end of the eighteenth century, few parishes remained in the hands of the orders. ${ }^{14}$ What is more, the process of secularization that arose from the deliberations of the Madrid junta after 1748 affected not only Peru, but also New Spain. In this case, as in others, policies and projects emanating from Superunda in Peru came to influence imperial policy itself, at the highest level. ${ }^{15}$ There is little doubt, then, that Superunda's close relationship with Ensenada had significant implications for the ways in

12. Catalina Vizcarra, "Bourbon Intervention in the Peruvian Tobacco Industry, 1752-1813," Journal of Latin American Studies 39:3 (August 2007): 567-593, esp. 569.

13. Charles F. Walker, Shaky Colonialism: The 1746 Earthquake-Tsunami in Lima, Peru, and Its Long Aftermath (Durham: Duke University Press, 2008), 117-122.

14. Kenneth J. Andrien, "The Coming of Enlightened Reform in Bourbon Peru: Secularization of the Doctrinas de Indios, 1746-1773," in Enlightened Reform in Southern Europe and its Atlantic Colonies, c. 1750-1830, Gabriel Paquette, ed. (Farnham, Surrey, UK: Ashgate, 2009), 183-202, esp. 196-199.

15. For New Spain, see Christoph Rosenmüller, “The Indians . . . Long for Change': The Secularization of Regular Parishes in Mid Eighteenth-Century New Spain," in Early Bourbon Spanish America: Politics and Society in a Forgotten Era (1700-1759), Francisco A. Eissa-Barroso and Ainara Vázquez Varela, eds. (Leiden: Brill, 2013), 43-63. 
which policy and reform were formulated and implemented in Peru during the active years around 1750 .

The Seville letters, as we shall see, are particularly revealing in the light they shed on this intense and productive relationship between a Spanish minister and his viceroy. But they are additionally valuable in their discussion of important affairs of state in a less guarded manner than is the usual in the official correspondence. On the one hand, we read Ensenada's bald conviction that although Peru is rich, "what it gives to the king [is] little, compared with its size, and what it produces." We learn also of his assumption that the viceroyalty's fiscal concerns are less urgent than those of the metropolis, and can therefore expect to wait longer for attention. In military affairs, we see Ensenada insisting that Spain's army and navy be reshaped on foreign models, but also deprecating the value of any standing force in the Americas: "What will defend the Indies in wartime are the fresh troops that will be sent from Spain." There is reference to the contemplated closure of the great mercury mines at Huancavelica in central Peru-almost the sole American source of the element required for refining silver in the mines of Peru, and sometimes even of Mexico-something nowhere else acknowledged in the official documentation of this period. ${ }^{16}$ And there are references to the king himself, Fernando VI, along with implied criticism of his father, Philip V, who had first appointed Ensenada in 1743 and who died in 1746, some months before the first of these letters was written.

\section{LONELy Fates}

Neither minister nor viceroy would enjoy happy endings to their lives and their illustrious careers. Ensenada was overthrown in a political coup in July 1754, and lived out the more than a quarter-century that remained to him largely in internal political exile in Spain. Superunda survived in Peru for seven years after the downfall of his friend and sponsor, until 1761, but his fate was worse. On his way back to Spain at the age of 74, he happened to be in Havana at the moment of its capture in 1762 by an overwhelming British naval force, and then fell victim to a spiteful personal campaign by the conde de Aranda, the head of the council charged with investigating the debacle. He was sentenced to ten years exile from the court and the forfeit of all his wealth and died in 1767, a broken man. ${ }^{17}$ There may be some small pathos, then, in reading these letters

16. See also Adrian J. Pearce, "Huancavelica 1700-1759: Administrative Reform of the Mercury Industry in Early Bourbon Peru," Hispanic American Historical Review 79:4 (November 1999): 669-702, esp. 697-698.

17. On this topic, see the striking essay by José Luis Gómez Urdáñez, "Víctimas ilustradas del despotismo: el conde de Superunda, culpable y reo, ante el conde de Aranda," in La corte de los Borbones, crisis del modelo cortesano, J. Martínez Millán, C. Camarero, and M. Luzzi, eds. (Madrid: Polifemo, 2013), 1003-1033. I thank the anonymous reviewer of this article for drawing my attention to this essay, and even supplying a copy of it with his or her report. 
between two apparently close officials vigorously concerned with the reform and revitalization of the Spain and Peru of their times.

\section{The Correspondence}

\section{MARQués de La ENSENAda To SUPERUNDA, SAN LORENZO EL REAL, NOVEMBER 30, 1745}

Archivo General de las Indias (AGI), Lima, leg. 642.

Cada día estoy más contento de haber propuesto al Rey fuese Vuestra Merced virrey del Perú, y Su Majestad persuadido está a que ha sido muy acertada la elección. Obre Vuestra Merced como le dictare su honor, y su conciencia, pues aquí se le sostendrá: y represente sobre lo que por sí no pueda hacer, para que se le envíen las órdenes necesarias. Debo insistir para que Vuestra Merced me socorra frecuentemente con caudales, pues la guerra dura, y puede durar años. Estos reinos están como Vuestra Merced puede considerar; y el que en ocasión tan crítica se haya echado mano de un Riojano, para llevar adelante esta máquina, debe empeñar a Vuestra Merced a ayudarme por todos los medios imaginables...

\section{Ensenada to Superunda, November 30, 1745}

Every day I feel happier at having suggested to the king that you should be viceroy of Peru, and His Majesty is convinced that the choice has been a most correct one. You should act as your honour and conscience dictate, since here you will be supported; and tell me what you cannot do by yourself, so you can be sent the necessary orders. I must insist on your assisting me often with funds, since the war goes on, and may go on for years; these kingdoms are in a state that you can well imagine; and the fact that, in such critical times, a Riojano should have been called upon to push this engine forward, must convince you to help me by every means imaginable.

\section{Conde de Superunda to Ensenada, Lima, August 12,1746}

AGI, Lima, leg. 642

El Real Patrimonio ... se contempla muy pingüe así por las providencias que he establecido como las que solicito de esa fuente a la que lo hago presente en sus respectivas oficinas.... Este país se halla con serenidad pues he sabido calmar las discordias entre frailes, tribunales y republicanos; sólo no ha alcanzado el fusil a encontrar el rebelde de las montañas de Tarma por las más eficaces 
diligencias practicadas, pues son sus retiros impenetrables. Ha decaído su séquito, y practicaré cuantas diligencias sean dables por romper este cascabel, que ya tiene poco sonido entre estas gentes.

\section{Superunda to Ensenada, Lima, August 12, 1746}

The Royal Patrimony ... promises to be very rich, both due to the measures I have introduced and those I am asking for from that source [the crown], as I am making clear to its different offices.... This country is at peace, since I have been able to calm the disagreements among friars, tribunals and citizens; only the musket has not yet reached the rebel of the jungles of Tarma, despite the most active steps taken, since they are his impenetrable retreat. ${ }^{18}$ His following has declined, and I will take such steps as I can to silence this little bell whose sound is already fading among the people here.

\section{Conde de Superunda to Ensenada, Lima, MARCH 30, 1748}

AGI, Lima, leg. 643

Paisano del Alma: Tengo tomadas las seguras medidas de hacer a la primavera otra remesa de 300,000 pesos y lo demás que el ingenio y arbitrios alcance, pues no quiero la paz sino Gibraltar y Mahón, y que nuestro suegro nos regale la Colonia, con lo que florecería este país, y la Corona.

Superunda to Ensenada, Lima, March 30, 1748

Countryman of my soul ... I have taken firm steps to make another remission of funds in the spring, of 300,000 pesos and whatever else ingenuity and my measures can yield, because I do not want peace, but rather Gibraltar and Mahón [Minorca], and for our father-in-law to give us Colonia, so that this country and the crown can flourish. ${ }^{19}$

\section{Marqués de la Ensenada to Superunda, Aranjuez, MAY 26, 1748}

AGI, Lima, leg. 643

Sea como fuera la paz, mucho peor sería la continuación de la guerra; y el Infante quedará establecido.... Es cierto, que según mi concepto, en dos años

18. Juan Santos Atahualpa, whose rebellion began in 1742 , and would last until 1752 .

19. Both Gibraltar and Mahón had been in British hands since the Treaty of Utrecht of 1713. The father-inlaw mentioned is King João V of Portugal, father of Barbara of Braganza, wife of Fernando VI of Spain. Colônia do Sacramento is the Portuguese settlement established on the north shore of the River Plate in 1680. 
de tranquilidad serán llevaderos los ahogos de esta desaliñada Hacienda, pero también lo es, que en los remates de una guerra, hay que hacer mayores gastos, que en lo fuerte de ella, no siendo pequeño el del viaje de Infantas madre, e hija, y ponerles la casa, y un todo.... Tengo presente cuanto habrá cargado sobre Vuestra Merced por los accidentes, que allí han sobrevenido; pero hágase Vuestra Merced cargo de que las urgencias de acá también son executivas, y que las de allí pueden dar alguna más espera, teniendo Vuestra Merced a la vista, los fondos de que podrá echar mano, y que acá se necesita más tiempo para juntar los precisos. Ese reino [Perú] es pingüe, lo que da al Rey poco, respecto a su extensión y lo que produce. Esto lo puede Vuestra Merced conocer más bien; y así pues tiene facultades, y se le darán todas las que quiera, reforme Vuestra Merced gastos, corte abusos, y establezca regularidad, y método, pues con sola la buena administración podrá Vuestra Merced adelantar mucho.

Esté Vuestra Merced en que mi sistema es no reformar ni un battallón, ni un escuadrón, antes bien aumentar aquellos, y que sean de extranjeros en disposición, también de poblar; pero no que nos lleven sus oficiales los grados, gobiernos, ni encomiendas, porque para todo esto hay españoles. La marina está caída y es menester que sea considerable, porque sin ella, y sin ejército no será nuestra España lo que puede, y debe ser... Si no hemos de engañar al Rey, ni unos a otros, debemos confesar, que lo que defenderá las Indias en tiempo de guerra será la tropa fresca, que vaya de España.

En lo que mira a audiencias, tribunales, etc, también es menester que Vuestra Merced meta la mano, tirando, en lo que le pareciere, la piedra, y escondiendo la mano, pues por esto estoy yo aquí, que tengo una espada muy larga, y muy libre para todo lo que sea justo, y obligación de extinguir abusos, y desórdenes.

Aunque no precisa, se ha pedido una bula a Roma, para que el Rey emplee todo el producto de Cruzada de América en los presidios, y defensa de ella... El papel sellado, lanzas, y medias annatas de títulos, y los empleos, alcabalas y otros ramos, y los demás, con especialidad el primer renglón, lo considero vergonzosamente abandonado... Bien creerá Vuestra Merced que si al comercio he guardado buena fe en tiempo de guerra, que mejor lo haré en el de paz, y en ella fundo el principal bien de esta Monarquía.

\section{Ensenada to Superunda, Aranjuez, May 26, 1748}

However the peace turns out, to continue the war would be much worse, and the Infante will be firmly established [in Parma]. ${ }^{20} \ldots$ In truth, in my opinion, within 
two years of peace the burdens on this feeble Exchequer will be tolerable, but it is also true that there are greater costs to be met in wrapping up a war than at its very height; those of the journey of the Infantas, mother and daughter, and setting up their house, and everything else, not the least. I am aware of how much will be weighing on you because of the unfortunate events that have taken place over there. ${ }^{21}$ But you must realize that the demands here are most urgent too, and that the ones there can wait a little longer, since you have before you funds you can make use of, and here more time is needed to amass what is required. That kingdom is rich, and what it gives to the king little, compared with its size, and what it produces. This you can understand better than I; and since you have the powers, and you will be given all that you wish, you should reduce costs, curb illicit practices, and introduce regularity and method, since only through good administration will you be able to make much progress.

You must understand that my plan is not to reform so much as a battalion, or a squadron, but rather to increase them, and make them foreign in organization, and also in the soldiery; but not to have their [foreign] officials fill the ranks, officerships, and commissions, because there are Spaniards for all that. The Navy is weak, and needs to be substantial, because without it or an army our Spain will not be what it can and must be.... If we are not to deceive the king, and each other, we must confess, that what will defend the Indies in wartime are the fresh troops that will be sent from Spain.

So far as the audiencias, tribunals, etc., are concerned also, it is necessary that you should take a hand in affairs, throwing the stone where you see fit, and hiding the hand, since that is what I am here for, and my sword is very long, and very free for all that is just, and [I have] the obligation to stamp out abuses and disorder.

Although there is no strict need, a bull has been sought from Rome, so that the king can devote the whole product of the American Cruzada to the forts and defence there... The stamped paper, lanzas, medias annatas on noble titles, and the offices, alcabalas, and other branches, and all the rest, especially the first of these, have I think been shockingly neglected ... ${ }^{22}$ You can well believe that if I have kept faith with trade during wartime, I will do so even more during the peace, and in it I base the principal good of this monarchy.

\section{Marqués de la EnSEnada to Superunda, Buen Retiro, August 17, 1748}

AGI, Lima, leg. 643

Amigo del alma: Como no hay que dudar de la paz, van órdenes consecuentes a la proximidad de desfrutar un tan grande bien. Pero los rezagos traen para

21. Probably refers mainly to the great Lima earthquake of October 1746

22. The lanza and the media annata were taxes levied on nobles in Spain and the colonies. 
mi más gastos en un par de años que la propia guerra. La tranquilidad, que espero en Dios dure, es menester aprovecharla en reglar por todas partes la Real Hacienda porque ésta es la que debe dar la ley para todo.

Con la de acá me voy ingeniando, y con suceso, como quizás habrá Vuestra Merced entendido de Orozco, y Escobedo, a quienes dirá Vuestra Merced mil cosas de mi parte, y también a Ortuño. ${ }^{23}$ Por lo que mira a la de Nueva España estoy contento del amigo Horcasitas, que corresponde a la confianza. La de allá está mucho más embrollada; pero es Vuestra Merced el virrey, y por eso me prometo aún más que de todas las demás partes. Facultades para ello se han concedido a Vuestra Merced, y si más quisiere, más se le darán.

En los gastos, que llaman de guerra, bien tiene Vuestra Merced qué remediar; y casi todos los demás se le parecen. Recelo que hay grandísimos desórdenes en pensiones, y compensaciones; y creo como de fe, que si Vuestra Merced no corta las cuentas, y establece una nueva, que ni lo atrasado se verificará, ni lo corriente irá claro. He consentido en que el estanco del tabaco ha de dar un copioso ingreso; y esta obra puramente de Vuestra Merced será. Conozco que carece Vuestra Merced de sujetos de habilidad, y de integridad; pero con el tiempo los hallará, y los criará, de que tengo yo experiencia en mis manejos. Socórrame Vuestra Merced bien, pues le repito que tengo mucho que gastar, porque si no se paga puntualmente ni ejército, ni marina, ni tribunales que hagan justicia puede tener el Rey; y si Su Majestad no se hace respetar en Europa, nos despreciarán más en América.

Yo quedo de Vuestra Merced siempre suyo de corazón.

\section{Ensenada to Superunda, Buen Retiro, August 17, 1748}

Friend of my soul: Since the peace cannot now be doubted, orders are being sent fit for the approach of our enjoyment of so great a good. But the loose ends bring me more costs in a couple of years than did the war itself. We must take advantage of the peace, which I hope to God endures, to set the Royal Exchequer in good order in all its parts, since that will lay the grounds for everything else.

I am grappling with [the Exchequer] here, and successfully, as perhaps you will have heard from Orozco and Escobedo, who you will give a thousand greetings from me, and also to Ortuño. ${ }^{24}$ As for [the Exchequer] in New Spain, I am happy with our friend Horcasitas, who is living up to the trust placed in him. [The Exchequer] over there is in much more of a muddle; but you are the viceroy, and so I expect

23. Francisco de Orozco, head of a small naval squadron that reached Peru from Spain in April 1748. References to the other two men are obscure.

24. See note 23 . 
more than from all the other territories. You have been given powers to do so, and should you wish for more, you will be given more.

In regard to the costs called wartime costs, you have much to set right; and almost all the others are in a similar state. I fear there is great disorder in pensions and compensations; and I believe as a matter of faith that if you do not reduce the accounts, and establish new ones, neither what is owed nor what is current can be known. I have agreed that the tobacco monopoly will give abundant income; and this will be entirely your undertaking. I know you lack people of skill and integrity; but with time you will find them, and train them, as I have found in my own affairs. Assist me, since I repeat that I have much to spend, because if we are not punctual in our payments the king can have neither army, nor navy, nor tribunals of justice; and if His Majesty does not make himself respected in Europe, they will despise us the more in America.

I remain yours always at heart.

\section{Marqués de la Ensenada to Superunda, Buen RETIRO, NOVEMBER 30, 1748}

AGI, Lima, leg. 643

Paisano, y amigo de mi vida: Celebro infinito, que continúen en Vuestra Merced las fuerzas de ánimo, y de cuerpo, pues las ha menester. Yo sin novedad en todo... Fue ésta una guerra contra pelo, y así no podíamos aspirar a mayor bien, que el de la paz. Ésta se ha conseguido, y con algún decoro, y muchas experiencias, de lo que son nuestros amigos, y nuestros enemigos, y de lo que puede ser la España medianamente gobernada. De esta escuela hemos menester aprovecharnos, y no dudo se consiga.... Muchas veces me acuerdo de que Vuestra Merced es Riojano, y yo también.... Ayúdeme Vuestra Merced, con los más caudales que pueda para poder dar sangre a este cuerpo, que está hecho un cadáver. Y ayudaré a Vuestra Merced con aprobaciones del Amo, ya que las merece, y con procurar le conste, que ponemos en respeto la Monarquía.

Casi he consentido en que enviándose de acá el azogue y cerrando la mina de Huancavelica, ganará el Rey, hará beneficio a esos vasallos, y preservará los Indios, que es el mayor negocio; pero para resolver, aguardo las noticias, que a Vuestra Merced y a Eslava he pedido.

Con el nuevo Arzobispo estará Vuestra Merced en gran harmonía; y deseo se vaya, para que unidos, hagan Vuestras Mercedes mil cosas buenas... Avise Vuestra Merced las bagatelas que apetezca de acá, porque yo quiero, y puedo enviárselas, y no sé cuales han de ser... En no pocas cosas para el Gobierno, y utilidad recíproca de esos, y estos reinos, estoy pensando; pero amigo 
mío, fáltame tiempo, y un hombre no puede hacer más, que lo que otro hombre.

Quedo de Vuestra Merced siempre suyo de corazón.

\section{Ensenada to Superunda, Buen Retiro, November 30, 1748}

Countryman, and friend of my life: I am infinitely happy that you continue to be strong in spirit and in body, since you will need it. No change here for me... This was a most difficult war, so that we could hope for no better end than that of the peace. This we have achieved, with some decorum, and much experience of who our friends are, and our enemies, and of what Spain can be if half well-governed. We must take advantage of this schooling, and I have no doubt we will... Very often I remember that you are a Riojano, and so am I.... Assist me with as much funds as you can, to give blood to this body, now little more than a corpse. And I will assist you with signs of approval from His Majesty, since you deserve them, and will try to make sure that he knows that we are making the Monarchy respected.

I have almost agreed that, [by] sending mercury from here and closing the Huancavelica mine, the king will benefit, as will those vassals, and the Indians will be preserved, which is the main affair; but to make a decision, I await the information that I have asked for from you and Eslava. ${ }^{25}$

You will live in great harmony with the new Archbishop; and I want him to set out, so that together you can do a thousand good things. . . ${ }^{26}$ Let me know what trinkets you would like from here, because I wish to and can send them to you, and I do not know what they should be ... I am pondering no small number of things for the government and mutual benefit of those kingdoms and of these [that is, Spanish America and Spain]; but my friend, I lack time, and one man can do no more than any other.

I remain always yours at heart.

\section{Marqués de la Ensenada to Superunda, Aranjuez, MAY 9, 1749}

AGI, Lima, leg. 643

Doy a Vuestra Merced gracias por sus reiteradas ofertas de remitirme caudales; y si viese lo justísimamente que se emplean, creeré, que de cualquiera parte los sacaría, o hurtaría, pues todo tiene por objeto el servicio de Dios, y el desagravio de esta Monarquía, en que tenemos por Rey el que habíamos menester para

25. Sebastián de Eslava, viceroy of New Granada from 1739 to 1749.

26. Pedro Antonio Barroeta y Ángel, with whom Superunda eventually developed an extremely tense relationship. 
hacerla respetable, y feliz; y Vuestra Merced no querrá, que a tan santos fines, dejemos de concurrir dos Riojanos, que para algo los ha puesto la divina providencia, de Virrey del Perú el uno, y el otro de ministro, pues por diligencias nuestras no estamos en estos empleos...

Póndrase cuidado en que las órdenes concediendo a Vuestra Merced facultades, que propone, no se refieran a sus representaciones; pero no se pare en esto ya que todos saben, que está muy sostenido del Rey, y de mi ministerio por su propio mérito, y no por pasión, y fines particulares. Irá contestado lo que Vuestra Merced propone sobre establecimiento por ahora de Secretario, etc., para lo de Hacienda, ya que lo de Intendente disuena tanto. No acudirán a mí Hesles, ni Escobedo en cosa, que pueda disonar a Vuestra Merced pues le conocen, y me conocen. ${ }^{27}$ Fue disparate enviar un Guipuzcoano donde había partidos de Vascongados, y Montañeses; pero a la deposición de Vuestra Merced es a lo que doy crédito.

Soy, y seré, de Vuestra Merced hasta morir.

\section{Ensenada to Superunda, Aranjuez, May 9, 1749}

I thank you for your repeated offers to send me funds; and if you saw just how well they are spent, I do believe that you would take them, or steal them, from wherever you could, since all is for the purpose of the service of God, and the relief of this Monarchy, in which we have as king he who we needed to make it respectable and happy; and you will not wish that we two Riojanos should fail to assist with such holy goals, when Divine Providence has placed one of us as viceroy of Peru and the other as minister for a reason, since we do not hold these posts through our own efforts.

Care will be taken to ensure that the orders conceding you the powers that you ask for do not refer to your reports, but you should take no notice of this, since everyone knows that you are greatly supported by the king and my ministry through your own merit, and not partiality and private ends. A reply will be sent on what you propose regarding the creation for now of a Secretary, etc., for Exchequer affairs, since the title of Intendant sounds so bad. Neither Hesles nor Escobedo will come to me with anything against you, since they know you, and they know me. It was absurd to send a Guipuzcoan somewhere there were parties of Basques and Montañeses; but it is your testimony that I give credit to.

I am and will be yours until death.

University College London

Adrian PEARCE

United Kingdom

27. Diego de Hesles, Superunda's viceregal secretary. 